Chapter 7

\title{
Transport of Nitrate and Ammonium During Tropical Storm and Hurricane Induced Stream Flow Events from a Southeastern USA Coastal Plain In-Stream Wetland - 1997 to 1999
}

\author{
J. M. Novak, A. A. Szogi, K.C. Stone, X. Chu, \\ D. W. Watts and M. H. Johnson
}

Additional information is available at the end of the chapter

http://dx.doi.org/10.5772/51152

\section{Introduction}

Nitrogen $(\mathrm{N})$ is an essential element for the functioning of aquatic ecosystems [1, 2]; however, when in excess, it can be detrimental to water quality by promoting eutrophication $[3,4]$ and growth of harmful microalgae and dinoflagellates [5]. Elevated N levels transported by streams and rivers into downstream coastal estuaries are of particular concern because eutrophication can affect up to $65 \%$ of the estuarine area of the coastal USA [6]. Eutrophication leads to hypoxia which stresses fish, shellfish, and invertebrates, and long-term exposure to hypoxia is fatal to most endemic fauna $[7,8]$. Rapidly growing and diversifying non-point and point sources of $\mathrm{N}$ (e.g. agricultural crop production, urban wastewater, fertilizer use, $\mathrm{N}$ enriched rainfall, and concentration of animal production systems) have been linked as causes for these troubling symptoms of eutrophication [9-12].

In eastern North Carolina, the Cape Fear River has experienced water quality issues due to high $\mathrm{N}$ input loads from non-point sources [13]. Mallin et al. [13] has linked water quality degradation in the Cape Fear River to N-enriched runoff from land areas with highly concentrated animal production. North Carolina has about 10 million pigs with the majority (58\% of state total) of production located within the Cape Fear River basin in four counties (Duplin, 
Sampson, Bladen, and Wayne) [14]. The Cape Fear and Lower Cape Fear Rivers flow through or receive input from small tributaries that drain watersheds within these four North Carolina counties. Nitrogen transported from small tributaries into the Cape Fear and Lower Cape Fear River systems has caused concern about water quality degradation [12, 15].

Non-point $\mathrm{N}$ movement into river and streams is a serious water quality issue in watersheds of the southeastern Coastal Plain region [16]. Nitrogen stored in soils or groundwater can move in runoff and in subsoil flow into rivers and streams especially after storm events [15] resulting in increased nutrient loading into downstream estuaries [13]. Because stream and rivers can readily transport $\mathrm{N}$ into estuaries, understanding processes that influence $\mathrm{N}$ cycling along the flow continuum offers the opportunity to shape best management strategies to reduce excess N movement. Galloway et al. [17] estimated that almost $50 \%$ of the $\mathrm{N}$ entering streams and rivers can be removed by $\mathrm{N}$ assimilative processes before it reaches coastal waters. Assimilative $\mathrm{N}$ processes in wetlands involves reactions between the water column and sediments [18, 19], and by microbial assimilation, denitrification and plant uptake [20, 21].

Wetlands are natural landscape features that provide an ecosystem service for $\mathrm{N}$ removal and are effective at reducing $N$ loads [22, 23] and concentrations [24]. Hunt et al. [23] showed that a North Carolina Coastal Plain in-stream wetland annually removed $3 \mathrm{~kg} \mathrm{~N}$ ha $^{-1} \mathrm{~d}^{-1}$ or about $37 \%$ of the total $\mathrm{N}$ as inflow. However, further examination of stream $\mathrm{N}$ export loads during direct runoff and base flow events as well as shifts between $\mathrm{N}$ storage pools within the wetland is needed to better understand $\mathrm{N}$ dynamics in this Coastal Plain ISW. It was hypothesized that greater $\mathrm{N}$ loads should be exported during periods of high stream outflows due to shifts in the wetland's N storage pools. This is a plausible premise because precipitation from storm events should increase stream inflows thus causing hydrologic disturbances within the wetland. In turn, these hydrologic disturbances stir up $\mathrm{N}$ associated with sediments, shifting equilibrium reactions between nutrients in the water column and sediment with increasing $\mathrm{N}$ losses with outflow. Wetland $\mathrm{N}$ storage/release dynamics are germane for this agriculturally intensive region of North Carolina because of the frequency of tropical storms and hurricane events $[25,26]$ and the subsequent increase in $\mathrm{N}$ movement into coastal estuaries $[9,13,5]$.

The data of this study was extracted from a decades-long data base gathered from a US Department of Agricultural Water Quality Demonstration Project. The 3-year hydrological data presented in this article contained significant tropical storm and hurricane activity that is still relevant today. Current hurricane activity and tropical storms projections suggest an increase in their activity due to climate variability. Thus causing a need for past data contributions for future model projections. The objectives were to $i$ ) estimate annual $Q_{t}, Q_{d r}$ and $Q_{b}$, and annual $\mathrm{N}$ (as $\mathrm{NO}_{3}-\mathrm{N}$ and $\mathrm{NH}_{4}-\mathrm{N}$ ) and calculate loads exported from the ISW during these events; and ii) ascertain annual shifts in $\mathrm{N}$ storage pools between $\mathrm{N}$ associated with sediment, the pore water and water column. 


\section{Materials and methods}

\subsection{Watershed and In-stream Wetland Description}

This study was carried out in the Herrings Marsh Run (HMR) watershed of Duplin Co., North Carolina. The HMR watershed is located in the Middle Coastal Plain region and is underlain with sandy to clay-enriched marine sediments [27]. The landscape topography is typical of the southeastern USA Coastal Plain possessing wide, nearly level to gently sloping upland areas, which have been dissected by primary, secondary and tertiary streams [27]. Soils that form in the upland areas are sandy with internal drainage ranging from somewhat poorly to excessively well-drained. Fairly wide (3-to 15-m) riparian zones form along streams resulting in floodplain areas containing very poorly drained soils [28].

For this study, daily precipitation totals were collected from both Warsaw and Clinton, North Carolina [29]. Technical information was gathered on characteristics of tropical storms and hurricanes (dates making North Carolina coastal contact, reported dates over Duplin Co., and daily precipitation) in reference [29].

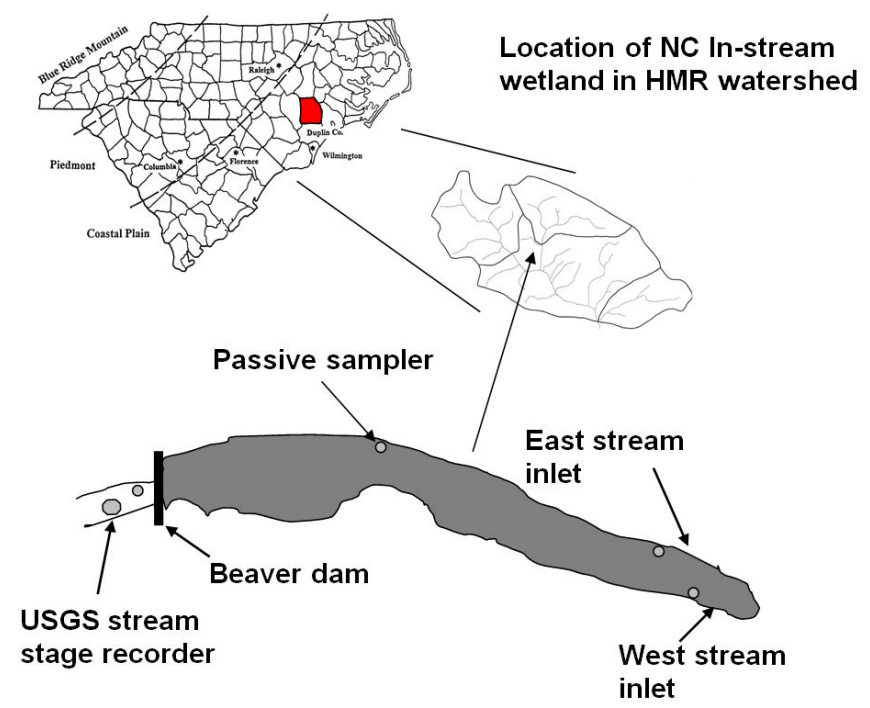

Figure 1. Location of the Herrings Marsh Run watershed in Duplin Country, North Carolina. The in-stream wetland was located at the outlet of a subwatershed and equipped with an outflow stage recorder with passive samplers installed at 4 different locations (outlet, mid-point, and two inlets).

Crop and animal production practices in the HMR watershed are typical for southeastern North Carolina [28]. This includes row and truck crop production and different livestock operations. Based on a 1993 animal survey of the HMR watershed, animal heads were estimat- 
ed at 29,931 for hog, 94,000 for poultry, and 176 for cattle [28]. Liquid animal manure from these operations is typically applied to row crops and pastures as a source of fertilizer.

In-stream wetlands in the HMR watershed are commonly formed in flat topographic locations and in shallow depressions along the stream continuum [27]. The studied wetland was located in the north central part of the watershed and is about 3.3 ha in size, has two diffuse stream inlets, storage volume of $29,000 \mathrm{~m}^{3}$, and the pond depth varied from $<0.3 \mathrm{~m}$ to almost $2 \mathrm{~m}$ deep (Figure 1). It receives inflowing water from two shallow second- and thirdordered black water streams on its eastern and western sides (Figure 1). This ISW is bordered by deciduous trees consisting of Bald Cyprus [Taxodium distchum L.], Swamp Chestnut Oak [Quercus michauxii Nutt.], Red Maple [Acer rubrum, L.], Green Ash [Faxinus pennsylvanica Marsh.], and both Loblobby [Pinus taeda, L.] and Longleaf [Pinus palustris, L.] pines. These trees offered a food source for colonization of the ISW by beavers (Castor Canadensis). Consequently, over several years, the beavers dammed up the outlet (Figure 2), which caused the two stream inflow locations to flood frequently.

\subsection{Stream Sampling Locations and Stream Flow Estimates}

In the early 1990s, both the east and west stream inlets flowed in well-defined stream channels. To measure water inflows, H-flumes were installed at these two inlets (Free Flow, Omaha, Nebraska ${ }^{+}$) equipped with pressure transducers [23]. Meanwhile, beavers improved the dam that slowed outflow and increased flooding which swamped both H- flumes. The flooding incidences lasted over several months causing inaccurate stream inflow measurements. So, there are no true inflow $Q$ measurements available for this study.

Outflow discharges from the ISW were measured as outlined in [23] using a U.S. Geological

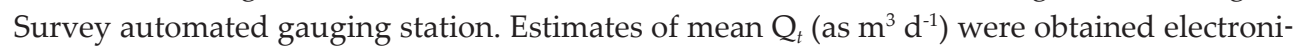
cally from $Q_{t}$ results that were recorded at 15-min intervals using an automated water level recorder. There were periods when daily $Q_{t}$ was not recorded due to equipment damage by storms and flooding, so a linear interpolation method was used to compute values for these missing periods. The daily $\mathrm{Q}_{t}$ results were further separated into $\mathrm{Q}_{d r}$ and $\mathrm{Q}_{b}$ using the digital filter method [30, 31]. This digital filtering method served to partition the total flow using equations 1 to 2 :

$$
\begin{gathered}
\mathrm{Q}_{d r, k}=\alpha \mathrm{Q}_{d r, k-1}+0.5(1+\alpha)\left(\mathrm{Q}_{t k}-\mathrm{Q}_{t k-1}\right) \\
\mathrm{Q}_{b, k}=\mathrm{Q}_{t k}-\mathrm{Q}_{d r, k}=0.5\left(\mathrm{Q}_{t k}+\mathrm{Q}_{t k-1}\right)-0.5 \alpha\left(\mathrm{Q}_{t k}-\mathrm{Q}_{t k-1}\right)-\alpha \mathrm{Q}_{d r, k-1}
\end{gathered}
$$

Where $\mathrm{Q}_{d r, k}=$ direct runoff at time step $k ; \mathrm{Q}_{b, k}=$ base flow at time step $k ; \mathrm{Q}_{t k}=$ total stream flow at time step $k$; and $\alpha=$ filter parameter. A $\alpha$ of 0.925 was used in the iterations [31]. Although there are method and assumption biases in this flow separation method, Nahatan and McMahon [31] recommend the use of the digital filter method when daily $Q_{t}$ results are available. Stream outflow samples were collected every $2 \mathrm{~h}$ using American Sigma automat- 
ic water samplers (Danaher Corp., Loveland, Colorado) and later combined to make composite 3.5-d samples.
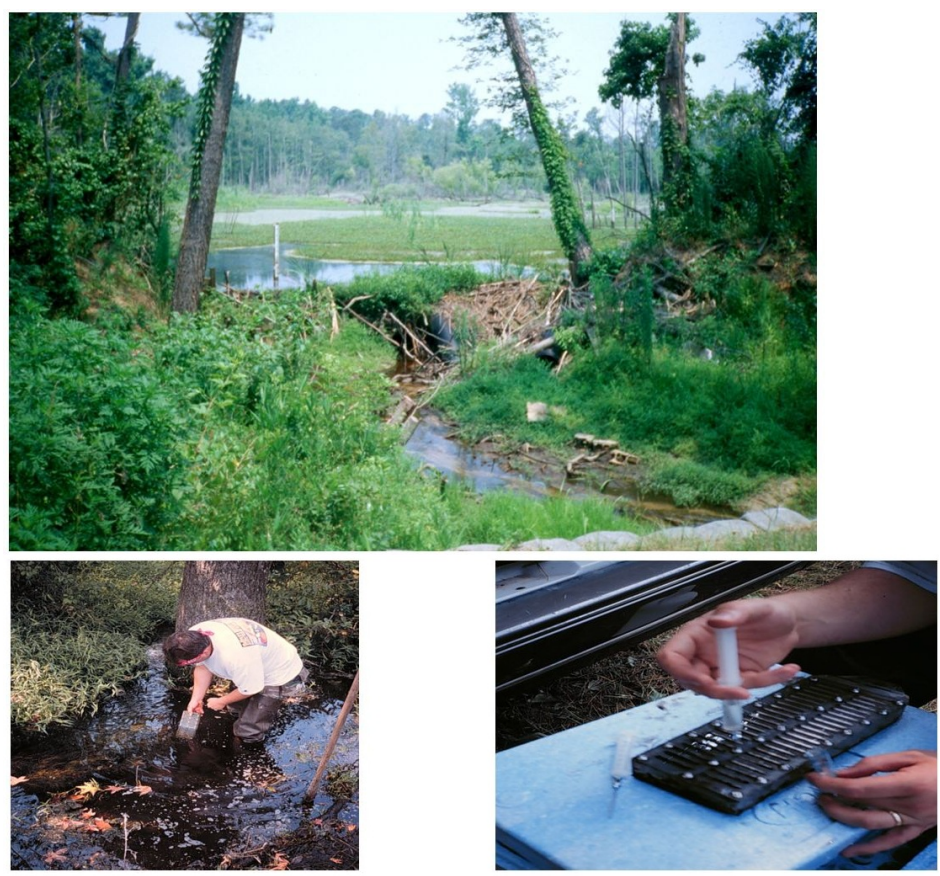

Figure 2. In-stream wetland outlet showing remnants of beaver dam (top), installation of passive samplers (bottom left), and removal of water sample using syringe from cells in passive sampler (bottom right).

\subsubsection{Dissolved N Measurements}

Sample preservation was accomplished by adding dilute $\mathrm{H}_{2} \mathrm{SO}_{4}$ to each automated water sampler bottle before sample collection. The acidified samples were collected weekly, filtered $(0.45 \mu \mathrm{m})$, and analyzed for $\mathrm{NH}_{4}-\mathrm{N}$ and $\mathrm{NO}_{3}-\mathrm{N}$ using a TRAACS 800 Auto-Analyzer (Bran + Luebbe, Buffalo Grove, Illinois) with EPA methods 353.2 and 350.1, respectively [32]. Quality control protocols for these analyses were outlined in reference [23].

\subsubsection{Dissolved N Mass Loads in Wetland Outflow}

From January 1997 to October 1999, daily outflow $\mathrm{NH}_{4}-\mathrm{N}$ and $\mathrm{NO}_{3}-\mathrm{N}$ mass loads $\left(\mathrm{kg} \mathrm{d}^{-1}\right)$ were calculated by multiplying the daily mean flows with $\mathrm{NH}_{4}-\mathrm{N}$ and $\mathrm{NO}_{3}-\mathrm{N}$ by using their interpolated concentrations over the 3-to 4-d interval [33]. In this data set, the missing stream $\mathrm{N}$ concentrations were linearly interpolated to provide their daily estimated concentrations, then were used to compute corresponding daily $\mathrm{N}$ loads. 


\subsection{Passive Samplers Installation, Sediment and Water Sample Collection}

Plexiglass passive samplers (peepers) were used to sample sediment pore water and the overlying water column according to procedures outlined in references [26, 33]. Each peeper consisted of a long block of plexiglass into which a series of cells spaced at 1-cm-depth increments were filled with deionized water and sealed with a membrane. Pairs of passive samplers were placed about 12-14 cm deep into the sediment at 4 locations (Figures 1 and 2) during a two-week period in Aug./Sep. during 1997, 1998 and 1999. Placement of the peepers at both ISW inlets were in shallow ( 0.2 to $0.4 \mathrm{~m}$ deep) areas, while placement at the midpoint and outlet sites was in deeper sections ( 0.5 to $0.8 \mathrm{~m}$ deep). Peepers were allowed to equilibrate with the sediment pore water and water column for 2 weeks. After removal of the peepers from the sediment, a plastic syringe was used to withdraw the sample from each cell in the peeper. The liquid sample was transferred into a plastic bottle containing dilute $\mathrm{H}_{2} \mathrm{SO}_{4}$ (preservative). The liquid samples were analyzed for $\mathrm{NH}_{4}-\mathrm{N}$ and $\mathrm{NO}_{3}-\mathrm{N}$ using the colorimetric method described earlier. Exchanges between water column and sediment $\mathrm{N}$ pools were determined by comparing relative differences in the water column and sediment pore water $\mathrm{NH}_{4}-\mathrm{N}$ and $\mathrm{NO}_{3}-\mathrm{N}$ concentrations. Sediment cores were also collected within $1 \mathrm{~m}$ of each peeper site using a bucket auger to $20 \mathrm{~cm}$ deep after peepers were installed. The sediments were air-dried and ground to pass a 2-mm sieve. The TKN concentrations were measured in all sediments using EPA method 351.2 [32]. Changes in the ISW N pools were determined by comparing relative differences in the annual sediment TKN and sediment pore water $\mathrm{NO}_{3}-\mathrm{N}$ and $\mathrm{NH}_{4}-\mathrm{N}$ concentrations.

\subsection{Statistics}

Outflow $\mathrm{Q}$ results, $\mathrm{N}$ concentrations and loads were initially computed on a daily basis and were also reported on a monthly and annual basis. This allowed for estimates of the cumulative $\mathrm{NO}_{3}-\mathrm{N}$ and $\mathrm{NH}_{4}-\mathrm{N}$ masses exported over the three-year study. To determine if the annual $\mathrm{N}$ loads (expressed as $\mathrm{kg} \mathrm{ha}^{-1}$ ) were dependent on outflow characteristics, the compiled mass of $\mathrm{NO}_{3}-\mathrm{N}$ and $\mathrm{NH}_{4}-\mathrm{N}$ by year were linearly regressed against the annual $Q_{t}$, estimates. This computation was accomplished by dividing the annual $\mathrm{N}$ loads by the subwatershed area (425-ha). All statistical analyses were performed using SigmaStat software version 3.5 (SSPS, Chicago, Illinois).

\section{Results and Discussion}

\subsection{Storm Activity}

In the Atlantic Ocean, a distinct tropical storm (TS)/hurricane season occurs from June $1^{\text {st }}$ to November $30^{\text {th }}$, with more frequent storm activity reported in August to September [34]. In this study, TS and hurricane activity was also active in August through September (Table 1). Tropical storm 1 in 1997 deposited $70 \mathrm{~mm}$ of precipitation over the watershed. This storm prompted an increase in $Q_{t}$ from the ISW from $872 \mathrm{~m}^{3} \mathrm{~d}^{-1}$ to $9.7 \times 10^{3} \mathrm{~m}^{3} \mathrm{~d}^{-1}$ within $24 \mathrm{~h}$ of the 
storm's cessation. Numerous smaller storms throughout 1997 deposited less precipitation totals on this subwatershed that caused minimal impacts on $Q_{t}$. In 1998, Hurricane Bonnie deposited $183 \mathrm{~mm}$ of precipitation on the watershed and increased $Q_{t}$ from $800 \mathrm{~m}^{3} \mathrm{~d}^{-1}$ to $51 \mathrm{x}$ $10^{3} \mathrm{~m}^{3} \mathrm{~d}^{-1}$ within 2 days past this hurricane.

The most severe storm activity occurred in 1999. In January, three fast moving storms (FMS), which passed over the watershed in 1-2 days, collectively deposited $250 \mathrm{~mm}$ of precipitation. As will be presented, these three FMS abruptly influenced $\mathrm{Q}_{t}$ and $\mathrm{NO}_{3}-\mathrm{N}$ export loads. For the remainder of 1999, 1 TS and 3 successive hurricanes, which passed over the watershed, delivered impressive precipitation amounts that caused extreme hydrological disturbances to the ISW.

\begin{tabular}{ccc}
\hline Month/year & Storm activity & Precipitation (mm) \\
\hline August 1997 & TS-1 & 70 \\
\hline August 1998 & Hurricane Bonnie & 183 \\
\hline January 1999 & Fast Moving Storms (FMS)-2, 3, and 4 & 250 \\
\hline July 1999 & TS-2 & 76 \\
\hline August 1999 & Hurricane Dennis & 166 \\
\hline September 1999 & Hurricane Floyd & 392 \\
\hline October 1999 & Hurricane Irene & 48
\end{tabular}

Table 1. Dates for tropical storms and hurricanes recorded over the study site and precipitation totals from these storm events.

\subsection{Annual Flows from the In-stream Wetland}

In accordance with storm activity presented in Table 1, annual $Q_{t}$ flows varied considerably across three years (Table 2). The lowest annual $Q_{t}$ occurred in 1997 which corresponds to the lowest annual precipitation total. The annual $Q_{t}, Q_{d r}$ and $Q_{b}$ for 1998 were higher than 1997 which was explained by the higher 1998 precipitation total. The highest $\mathrm{Q}_{t}$ occurred in 1999 in response to 3 FMS, 1 TS and 3 hurricane events (Dennis, Floyd, and Irene) which collectively deposited 326 and $831 \mathrm{~mm}$ of precipitation, respectively. In particular, the collective precipitation total from these three hurricanes accounted for $47 \%$ of the total annual 1999 precipitation total. Correspondingly, the highest annual $\mathrm{Q}_{d r}$ and $\mathrm{Q}_{t}$ flow from the ISW were measured in 1999, which indicates a tremendous amount of runoff entered this ISW in only a 3-month period.

Our flow monitoring results, however, showed that most water exited this ISW during base flow periods. In all three years, $\mathrm{Q}_{b}$ values from the ISW were higher than $\mathrm{Q}_{d r}$ with $\mathrm{Q}_{b}$ events accounting for 53 to $75 \%$ of the $Q_{t}$. The higher $Q_{b}$ values implies that this ISW receives over $60 \%$ of its water supply through ground water recharge. It is not uncommon for stream $Q_{b}$ to exceed $\mathrm{Q}_{d r}$ flows exiting watersheds in the Eastern USA Coastal Plain region [35]. 


\begin{tabular}{ccccccc}
\hline & & \multicolumn{3}{c}{$\mathbf{Q}\left(\mathbf{m}^{\mathbf{3}} \mathbf{\times} \mathbf{1 0}^{\mathbf{3}}\right)$} & \multicolumn{3}{c}{ Flow as a percentage of $\mathbf{Q}_{\boldsymbol{t}}$} \\
\hline Year & Precipitation $(\mathrm{mm})$ & $\mathrm{Q}_{t}$ & $\mathrm{Q}_{d r}$ & $\mathrm{Q}_{b}$ & $\mathrm{Q}_{d r}$ & $\mathrm{Q}_{b}$ \\
\hline 1997 & 1190 & 1523 & 554 & 968 & 36 & 64 \\
\hline 1998 & 1410 & 1926 & 589 & 1337 & 31 & 69 \\
\hline 1999 & 1756 & 8980 & 3226 & 5754 & 36 & 64
\end{tabular}

Table 2. Annual precipitation near the study area, and total $\left(Q_{t}\right)$, direct runoff $\left(Q_{d r}\right)$, and base $\left(Q_{b}\right)$ flows estimated from the in-stream wetland.

\subsection{Dissolved N Loads Exported from the In-Stream Wetland}

\subsubsection{Total Dissolved N Exports}

Quantities of $\mathrm{N}$ exported from the ISW were expressed as a function of annual Q totals (Table 3) and as annual cumulative totals (Figure 3). The annual total quantity of both $\mathrm{NO}_{3}-\mathrm{N}$ and $\mathrm{NH}_{4}-\mathrm{N}$ exported from the ISW was variable. For instance, annual $\mathrm{NO}_{3}-\mathrm{N}$ export ranged from 4910 to $24,255 \mathrm{~kg}$ and $\mathrm{NH}_{3}-\mathrm{N}$ loads ranged from 778 to $1852 \mathrm{~kg}$ (Table 3). In 1997, more $\mathrm{NO}_{3}-$ $\mathrm{N}$ and $\mathrm{NH}_{4}-\mathrm{N}$ were exported during $\mathrm{Q}_{b}$ which is consistent with the majority (64\%) of ISW outflow occurring as $\mathrm{Q}_{b}$ (Table 2). The monthly amounts of $\mathrm{NO}_{3}-\mathrm{N}$ exported increased gradually during 1997 (Figure 3). There was a pulse in $\mathrm{NH}_{4}-\mathrm{N}$ exported during June to August 1997 in response to increased outflows from TS-1 (Table 1). In 1998, more $\mathrm{NO}_{3}-\mathrm{N}$ was exported from the ISW than in 1997, which is reflective of the higher annual precipitation total (Table 2) and corresponding $\mathrm{Q}_{t}\left(1926 \mathrm{~m}^{3} \times 10^{3}\right)$. The cumulative monthly export of both $\mathrm{NO}_{3}-\mathrm{N}$ and $\mathrm{NH}_{4}-\mathrm{N}$ over 1998 was gradual, with no major pulses observed (Figure 3). It should be noted that there were small pulses of $\mathrm{NO}_{3}-\mathrm{N}$ and $\mathrm{NH}_{4}-\mathrm{N}$ exported from the ISW (144 and $37 \mathrm{~kg}$, respectively) over the three days that Hurricane Bonnie delivered $183 \mathrm{~mm}$ of precipitation (Table 1). But, these pulses were indistinguishable in the cumulative export curves (Figure 3).

\begin{tabular}{cccccc}
\hline & \multicolumn{3}{c}{ Mass exported $(\mathbf{k g})$} & \multicolumn{2}{c}{ Mass as \% of total } \\
\hline Year & $\mathbf{Q}_{t}$ & $\mathbf{Q}_{d r}$ & $\mathbf{Q}_{b}$ & $\mathbf{Q}_{d r}$ & $\mathbf{Q}_{b}$ \\
\hline 1997 & 4910 & 1435 & 3475 & 29 & 71 \\
\hline 1998 & 9961 & 2740 & 7176 & 28 & 72 \\
\hline 1999 & 24255 & 7192 & 17063 & 30 & 70 \\
\hline \hline 1997 & & mean & 29 & 71 \\
\hline 1998 & 778 & & $\mathrm{NH}_{4}-\mathrm{N}$ & 57 \\
\hline 1999 & 453 & 333 & 445 & 43 & 65 \\
\hline & 1852 & 694 & 1158 & 35 & 63 \\
\hline
\end{tabular}

Table 3. Annual mass estimates of dissolved $\mathrm{NO}_{3}-\mathrm{N}$ and $\mathrm{NH}_{4}-\mathrm{N}$ exported from the in-stream wetland during total $\left(\mathrm{Q}_{t}\right)$, direct runoff $\left(Q_{d r}\right)$, and base $\left(Q_{b}\right)$ flow events. 


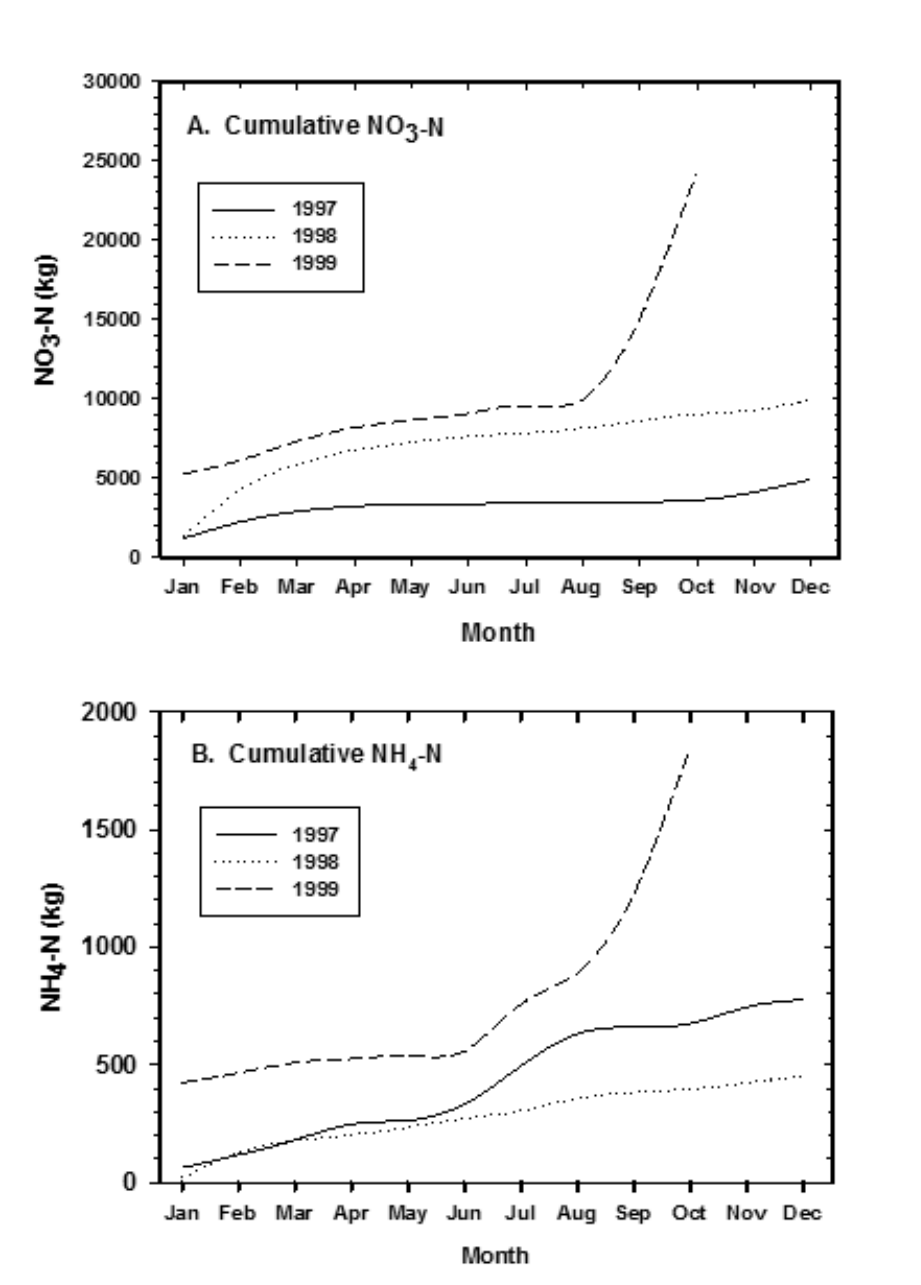

Figure 3. Cumulative annual dissolved $\mathrm{NO}_{3}-\mathrm{N}(\mathrm{A})$ and $\mathrm{NH}_{4}-\mathrm{N}(\mathrm{B})$ mass exported from the ISW.

\subsubsection{Base Flow Dissolved N Export}

In spite of the storm activity, most of the $\mathrm{NO}_{3}-\mathrm{N}$ and $\mathrm{NH}_{4}-\mathrm{N}$ as a percentage of the $\mathrm{Q}_{t}$ were exported from the ISW during $\mathrm{Q}_{b}$ events (Table 3). Annual base flows accounted for 70 to $72 \%$ and 57 to $65 \%$, respectively, of $\mathrm{NO}_{3}-\mathrm{N}$ and $\mathrm{NH}_{4}-\mathrm{N}$ exported. Others have reported similar results that more $\mathrm{N}$ is exported during $\mathrm{Q}_{b}$ than $\mathrm{Q}_{d r}$ events $[35,36]$.

The greater $\mathrm{N}$ masses transported during $\mathrm{Q}_{b}$ events implies that most of the $\mathrm{N}$ entering this ISW occurred during ground water recharge. This deduction is supported in reference [37] 
which reported that $\mathrm{NO}_{3}-\mathrm{N}$ discharge rates were greater for watersheds having soil or aquifer characteristics favoring $\mathrm{NO}_{3}-\mathrm{N}$ infiltration and subsurface flow. The sandy, agricultural soils in the southeastern Coastal Plain region indeed have these soil and geological features. Stone et al. [38] reported that in localized areas of the HMR watershed, farms that over-applied animal manure effluent had ground water $\mathrm{NO}_{3}-\mathrm{N}$ concentrations exceeding $20 \mathrm{mg} \mathrm{L}^{-1}$. This supports the contention that rapid infiltration coupled with lateral flow can facilitate $\mathrm{NO}_{3}-\mathrm{N}$ leaching out of the root zone that later emerges into streams. Therefore, more $\mathrm{NO}_{3}-\mathrm{N}$ transport during stream $\mathrm{Q}_{b}$ events implies that $\mathrm{NO}_{3}-\mathrm{N}$ infiltration is a more predominant mechanism of $\mathrm{N}$ transport than direct runoff. The $\mathrm{NO}_{3}-\mathrm{N}$ transport mechanisms between soil and ground water, however, can be dramatically altered by storm events that favor $\mathrm{NO}_{3}-\mathrm{N}$ movement into the ISW via flooding or as direct runoff.

\subsubsection{Direct Runoff Dissolved N Export}

Over three years, $\mathrm{NO}_{3}-\mathrm{N}$ and $\mathrm{NH}_{4}-\mathrm{N}$ exported during $\mathrm{Q}_{d r}$ events from this ISW accounted for 29 to $43 \%$ of the total annual mass loads, respectively (Table 3). In 1999, however, there was a large increase in both $\mathrm{N}$ forms exported during $\mathrm{Q}_{d r}$ that prompted a closer inspection of results. The results gathered in 1999 were scrutinized to report daily precipitation totals along with a hydrograph sorted by flow events and coupled with daily $\mathrm{NO}_{3}-\mathrm{N}$ export estimates (Figure 4). Nitrate was selected for presentation instead of $\mathrm{NH}_{4}-\mathrm{N}$ simply due to the sheer mass export size differences. During January 1999, three FMS events collectively delivered $250 \mathrm{~mm}$ of precipitation within the subwatershed. These storms caused a moderate rise is $Q_{t}$, but also a huge increase in $\mathrm{NO}_{3}-\mathrm{N}$ was exported $\left(5248 \mathrm{~kg}\right.$ ). The large spike in $\mathrm{NO}_{3}-\mathrm{N}$ load exported during January was attributed to abundant water column $\mathrm{NO}_{3}-\mathrm{N}$ concentrations (monthly mean $=6.17 \pm 1.55 \mathrm{mg} \mathrm{L}^{-1}$ ) exiting the ISW. For comparison, monthly mean $\mathrm{NO}_{3}-\mathrm{N}$ concentrations during the warmer months of June to September were much lower at 0.84 to $3.13 \mathrm{mg} \mathrm{L}^{-1}$, respectively. The higher $\mathrm{NO}_{3}-\mathrm{N}$ concentrations during the winter month of January are consistent with reduced $\mathrm{N}$ assimilation from slowed plant uptake and denitrification processes in a Coastal Plain wetland [23].

Precipitation amounts during February through July were not eventful as noted by the small spikes in the $\mathrm{Q}$ hydrograph and $\mathrm{NO}_{3}-\mathrm{N}$ chemograph (Figures $4 \mathrm{~B} \& \mathrm{C}$ ). Toward the end of the traditional hurricane season, however, large amounts of precipitation (Figure 4 A, 831 $\mathrm{mm}$ ) from the three successive hurricanes fell on the watershed causing gross hydrologic disturbances and corresponding higher $\mathrm{Q}_{t}$ (Figure $4 \mathrm{~B}$ ). These hurricanes also induced more $\mathrm{Q}_{d r}$ as noted by the numerous spikes from September to October (Figure 4 B). In turn, the $\mathrm{NO}_{3}-\mathrm{N}$ chemograph responded to these hydrologic disturbances by showing dramatic increases in mass export. In fact, between October $1^{\text {st }}$ and $24^{\text {th }}$, which had the subwatershed draining precipitation from Hurricanes Floyd and Irene, almost $9200 \mathrm{~kg}$ of $\mathrm{NO}_{3}-\mathrm{N}$ was exported from the ISW. Our results from 1999 imply that N storage by this ISW can be overwhelmed through hydrologic disturbances from storms during both non-hurricane and hurricane seasons. 


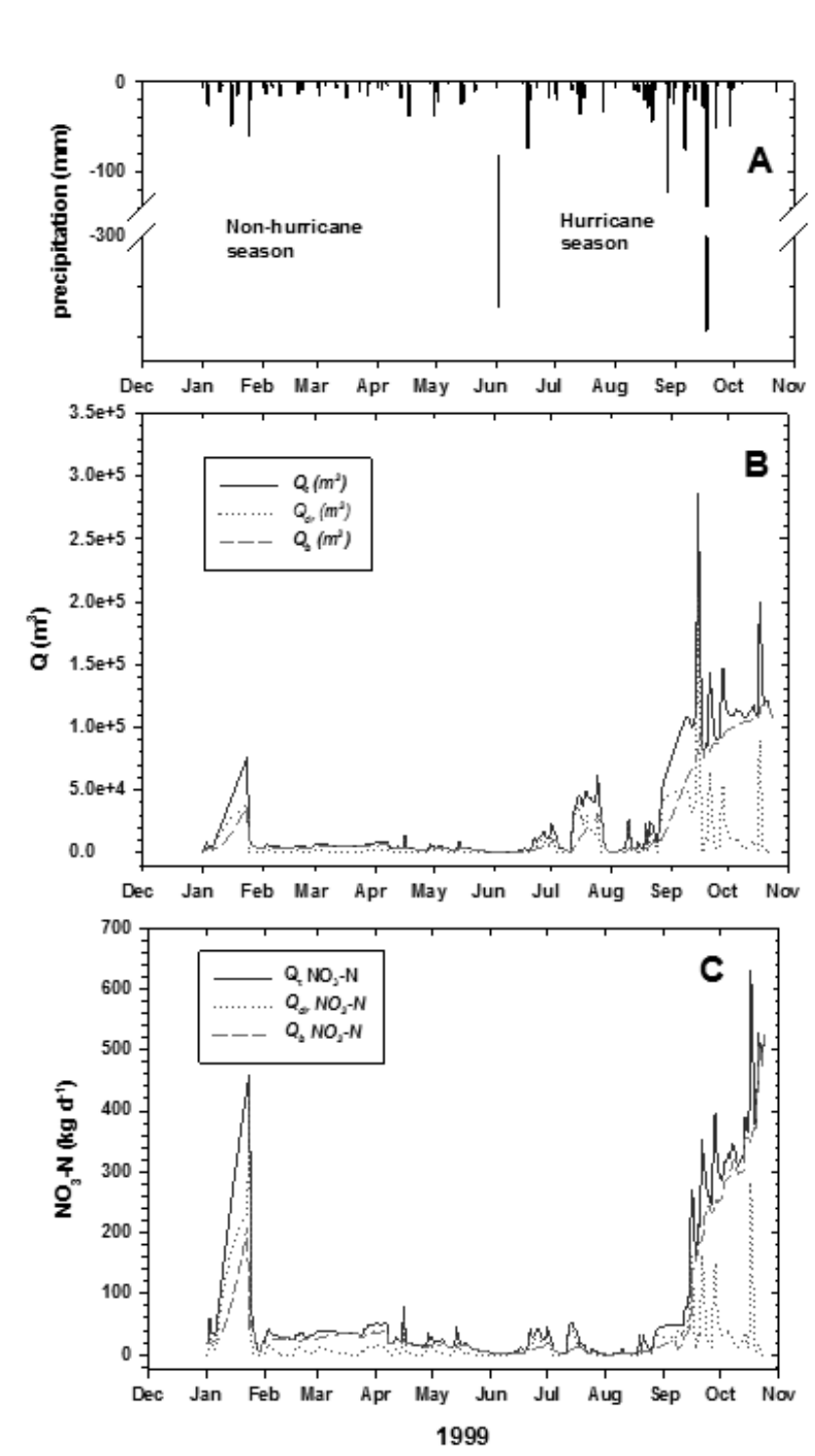

Figure 4. Daily precipitation, outflows and dissolved $\mathrm{NO}_{3}-\mathrm{N}$ exported from the ISW during 1999.

This ISW was found to release dissolved $\mathrm{N}$ due to storm precipitation and subsequent outflows. As more outflow occurred, correspondingly higher $\mathrm{NO}_{3}-\mathrm{N}$ and $\mathrm{NH}_{4}$ masses were transported out. To quantify the strength of this assertion, linear regression analyses were used to determine if daily $\mathrm{NO}_{3}-\mathrm{N}$ and $\mathrm{NH}_{4}-\mathrm{N}$ mass exported from the ISW were dependent on daily $\mathrm{Q}_{t}$ (Table 4). Regression analyses revealed that the exported $\mathrm{NO}_{3}-\mathrm{N}$ and $\mathrm{NH}_{4}-\mathrm{N}$ 
mass loads were significantly dependent on $Q_{t}$; however, the strength of the predicted changes was weak to strong $\left(\mathrm{r}^{2}\right.$ between 0.21 and 0.92$)$. There was a predictably stronger ability in 1998 to estimate daily $\mathrm{N}$ loads as a function of $\mathrm{Q}_{t}$, but the strength of the relationship weakened in 1997 and 1999. Arguably, there are other processes not considered in this relationship that will influence $\mathrm{N}$ export loads from this ISW such as sediment associated $\mathrm{N}$ losses, $\mathrm{N}$ sequestered by biological systems, or the rate of $\mathrm{N}$ exchange between the water column and sediments. Nonetheless, this study demonstrates that this ISW's ability to store $\mathrm{N}$ forms can be compromised as outflow increases.

\begin{tabular}{cccccc}
\hline year & $\mathbf{n}$ & Slope $\left(\mathbf{x} \mathbf{1 0}^{-8}\right)$ & $\mathbf{Y}_{\text {int }}$ & $\mathbf{r}^{\mathbf{2}}$ & $\mathbf{P}$ \\
\hline $\mathrm{NO}_{3}-\mathrm{N}$ & & & & & \\
\hline 1997 & 365 & 278 & 1.84 & 0.40 & $<0.001$ \\
\hline 1998 & 364 & 510 & 0.21 & 0.92 & $<0.001$ \\
\hline 1999 & 297 & 224 & 13.92 & 0.62 & $<0.001$ \\
\hline $\mathrm{NH}_{4}-\mathrm{N}$ & & & & & \\
\hline 1997 & 365 & 67.5 & -0.68 & 0.21 & $<0.001$ \\
\hline 1998 & 365 & 25.9 & -0.13 & 0.71 & $<0.001$ \\
\hline 1999 & 294 & 16.5 & 1.27 & 0.35 & $<0.001$
\end{tabular}

Table 4. Linear regression response between total $\left(Q_{t}\right.$ as $\left.L d^{-1}\right)$ outflow and pooled daily dissolved nitrate $\left(\mathrm{NO}_{3}-\mathrm{N}\right)$ and ammonium $\left(\mathrm{NH}_{4}-\mathrm{N}\right)$ mass loads exported $\left(\mathrm{kg} \mathrm{d}^{-1}\right)$ from the in-stream wetland.

\subsection{Nitrogen Storage Pools Within the In-stream Wetland}

Nitrogen storage processes within a wetland involve many pathways distributed between several biotic and abiotic sources [20]. In this study, abiotic $\mathrm{N}$ storage pools were examined such as $\mathrm{N}$ associated with sediments (as TKN) and soluble $\mathrm{N}$ forms in the water column and sediment pore water. The relative changes in $\mathrm{N}$ concentrations associated with sediments and between pore water and the water column provided a snapshot of $\mathrm{N}$ accretion and losses. The $\mathrm{NO}_{3}-\mathrm{N}$ and $\mathrm{NH}_{4}-\mathrm{N}$ concentrations were measured in the water column and sediment pore water using passive samplers (peepers) at three locations within the ISW, in sediments below the beaver dam (Figure 1), and by collecting sediments near these same locations and determining their TKN concentrations (Table 5).

At both inlet locations, there were $<11 \mathrm{mg} \mathrm{L}^{-1}$ of $\mathrm{NO}_{3}-\mathrm{N}$ in the water column and, by 1999, the concentrations declined to $<7 \mathrm{mg} \mathrm{L}^{-1}$ (Figure 5). The general decline in water column $\mathrm{NO}_{3}-\mathrm{N}$ at both inlets was likely due to flushing of the stream sediments and riparian areas due to storm events during 1997, 1998 and 1999 [26]. The relative $N$ concentrations between the water column and sediment pore water are important parameters to compare because they can be used to determine the gradient direction and subsequent nutrient movement response across the interface [39-41]. In all situations, sediment pore water $\mathrm{NO}_{3}-\mathrm{N}$ concentrations at these inlets are lower than the water column, implying that the concentration 
gradient would cause $\mathrm{NO}_{3}-\mathrm{N}$ movement across the sediment water column interface resulting in transfer into the sediments. The $\mathrm{NO}_{3}-\mathrm{N}$ equilibrium exchange into the sediment phase is probably accentuated through denitrification by microbial communities [19, 23]. As more $\mathrm{NO}_{3}-\mathrm{N}$ is consumed by denitrifying communities in the sediments, a concentration gradient will be created and cause its movement downward. This is a plausible explanation since the $\mathrm{NO}_{3}-\mathrm{N}$ concentrations declined rapidly as a function of sediment depth. In fact, the $\mathrm{NO}_{3}-\mathrm{N}$ concentrations declined to near zero between 1 and $3 \mathrm{~cm}$ deep at the East inlet (Figure 5).

At the Mid-point of the ISW, the water column $\mathrm{NO}_{3}-\mathrm{N}$ concentrations over three years showed similar decline behavior as measured at the East inlet. In that, higher $\mathrm{NO}_{3}-\mathrm{N}$ concentrations occurred in 1998 than in 1997. But both of these sites (East inlet and Mid-point) experienced a sizable $\mathrm{NO}_{3}-\mathrm{N}$ concentration decline in 1999. Similarly, $\mathrm{NO}_{3}-\mathrm{N}$ concentrations declined substantially within a few $\mathrm{cm}$ below the water column-sediment interface. Likewise to the $\mathrm{NO}_{3}-\mathrm{N}$ concentration gradient that occurred at both inlets, the lower sediment pore concentrations at the Mid-point over the three years would cause an equilibrium gradient shift resulting in its transfer into the sediment pore water. The downward $\mathrm{NO}_{3}-\mathrm{N}$ movement into the sediments would again cause it to be consumed by denitrifying organisms and hence its concentration declines in pore water (Figure 5).

At the outlet, water column $\mathrm{NO}_{3}-\mathrm{N}$ concentration declined to $<0.25 \mathrm{mg} \mathrm{L}^{-1}$ during 1997 and 1999, but in 1998 was as high as $3 \mathrm{mg} \mathrm{L}^{-1}$. Sediment pore water at the outlet during the three years was almost devoid $\left(<0.5 \mathrm{mg} \mathrm{L}^{-1}\right)$ of $\mathrm{NO}_{3}-\mathrm{N}$, suggesting that intensive denitrification prompted its removal from the water column.

Monitoring $\mathrm{NO}_{3}-\mathrm{N}$ concentrations in the water column and sediment pore water during the 2-week window along a flow gradient illustrated that this ISW had episodes showing outflowing $\mathrm{NO}_{3}-\mathrm{N}$ concentration reductions. Nitrate consumption by denitrifying organisms in the ISW sediments is suspected as being involved with its removal. Low outflow $Q_{t}$ during the summer months could have facilitated $\mathrm{NO}_{3}-\mathrm{N}$ diffusion across the sediment interface and subsequent $\mathrm{N}$ removal by denitrification. This removal mechanism was probably overwhelmed by storm events that accelerated $\mathrm{NO}_{3}-\mathrm{N}$ export with outflowing water faster than could diffuse across the sediment interface and be consumed by the denitrifying microbial community.

Monitoring $\mathrm{NH}_{4}-\mathrm{N}$ concentrations using peepers along the ISW flow continuum indicated some different dynamics relative to $\mathrm{NO}_{3}-\mathrm{N}$. The $\mathrm{NH}_{4}-\mathrm{N}$ concentrations in the water column ranged from $<1$ to as high as $6 \mathrm{mg} \mathrm{L}^{-1}$ (Figure 6). At all four locations, the $\mathrm{NH}_{4}-\mathrm{N}$ concentrations declined in a direction towards the sediment-water column interface. Szögi et al. [19] reported in flooded sediment, both nitrification and denitrification can occur at the same time. Similarly, the noted decline may be due to $\mathrm{NH}_{4}-\mathrm{N}$ being nitrifying by microbial communities and suggests the presence of aerobic zones above the interface allowing for organisms to conduct this oxidation [42]. The $\mathrm{NO}_{3}-\mathrm{N}$ product from this reaction could later diffuse down into the anaerobic zones in the sediments and be removed through denitrification reactions as shown by the $\mathrm{NO}_{3}-\mathrm{N}$ depletion with sediment depth (Figure 5). 

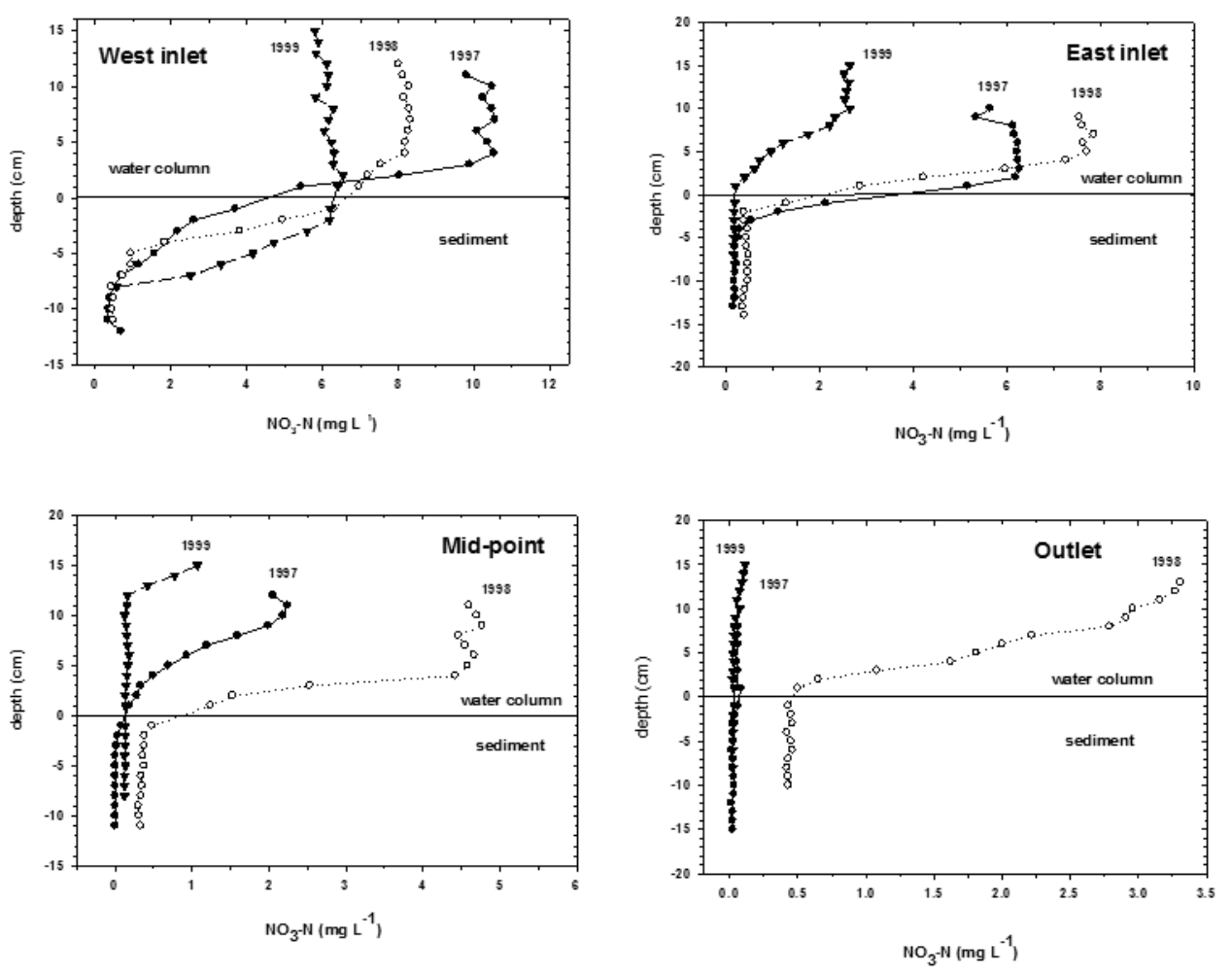

Figure 5. Nitrate $\left(\mathrm{NO}_{3}-\mathrm{N}\right)$ concentrations measured in the water column and sediment at location in the in-stream wetland (1997 to 1999).

Once oxygen diffusion into the sediments becomes limited, however, the sediments will become more anaerobic thus favoring $\mathrm{NH}_{4}-\mathrm{N}$ accumulation. Ammonium does accumulate in the sediment pore water at all four locations (Figure 6). Their concentrations ranged from $<1$ to almost $11 \mathrm{mg} \mathrm{L}^{-1}$. Accumulated $\mathrm{NH}_{4}-\mathrm{N}$ in sediment pore water can move upward across the interface into the water column $[19,43]$. Upward diffusion of $\mathrm{NH}_{4}-\mathrm{N}$ would occur in this system because the water columns have lower concentrations than the sediment pore water. Predictability, sediments in this ISW can act as an N source for the overlying water column because of $\mathrm{NH}_{4}-\mathrm{N}$ storage in sediments. Once diffused upward into aerobic zones, it can be nitrified to $\mathrm{NO}_{3}-\mathrm{N}$ during low flow conditions. During higher flow conditions, $\mathrm{NO}_{3}-\mathrm{N}$ would transfer with outflowing water and move down system. The balance between $\mathrm{NH}_{4}-\mathrm{N}$ upward movement, $\mathrm{NO}_{3}-\mathrm{N}$ consumption, or removal will be a function of stream flow as well as other processes (plant uptake, ammonia volatilization, etc.) known to affect $\mathrm{N}$ dynamics in wetlands $[19,20]$. 


\begin{tabular}{|c|c|c|c|}
\hline Location & 1997 & 1998 & 1999 \\
\hline \multicolumn{4}{|c|}{--- } \\
\hline East inlet & 665 & 617 & 2536 \\
\hline West inlet & 237 & 203 & 137 \\
\hline Midpoint & 3371 & 4337 & 548 \\
\hline Outlet & 854 & 291 & 322 \\
\hline
\end{tabular}

Table 5. Sediment Total Kjedhal Nitrogen (TKN) concentrations measured at various in-stream wetland locations.
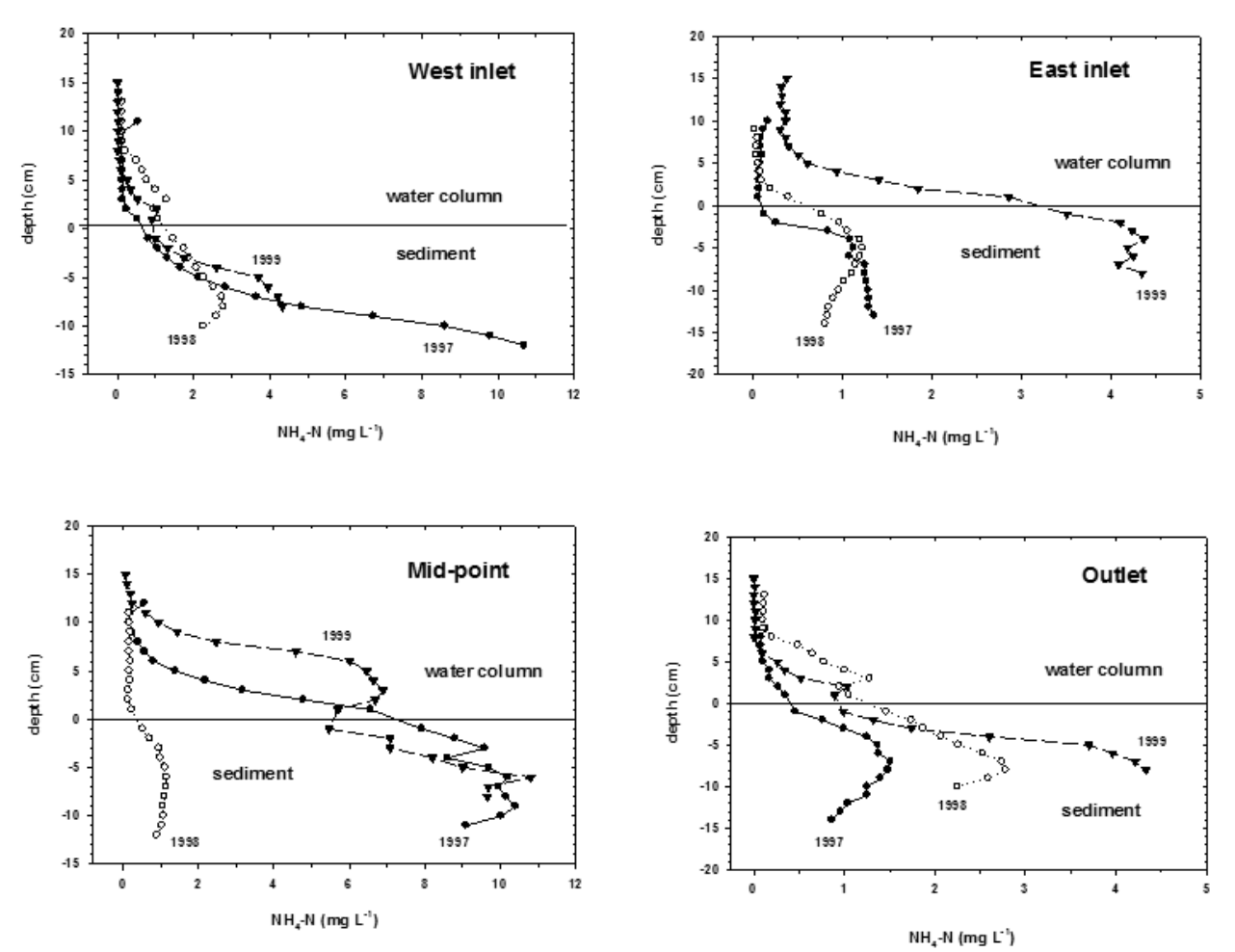

Figure 6. Ammonium $\left(\mathrm{NH}_{4}-\mathrm{N}\right)$ concentrations measured in the water column and sediment at locations in the instream wetland (1997 to 1999).

The TKN content of the ISW sediments was measured in core samples collected when peepers were installed (Table 5). These samples provided a snap-shot of TKN contents in sediments along the flow continuum. The East inlet had higher TKN contents than the West inlet during all three sampling years. The increase in TKN content in sediments at the West inlet between 1997 and 1999 was sizable (almost 4-fold). This may be attributable to reloca- 
tion of sediment enriched $\mathrm{N}$ from upstream riparian sources and/or $\mathrm{N}$ leakage from a nearby retired swine lagoon as a result of storm activity 1 to 2 months before collection [28]. On the other hand, the ISW can store $\mathrm{N}$ associated with sediments because some of the highest TKN contents were measured in 1997 and 1998 at its Mid-point. Between 1998 and 1999 at the Mid-point, however, there was almost an 8-fold decline in TKN content. Likewise, there was a 3-fold decline in TKN concentration at the outlet. The noted shift in sediment TKN contents implies that water flowing through the East inlet was an apparent $\mathrm{N}$ source for this ISW and that storm activity between 1998 and 1999 considerably reduced sediment TKN contents. As outlined [26], this ISW was inundated in 1999 with a tropical storm and Hurricane Dennis a few months before sediment collection and peeper installation. It is plausible that shifts in sediment TKN concentrations were in response to hydrologic disturbances created by these storms. As shown in Fig. 4 C, Hurricane Dennis in mid-Sep. 1999 greatly accelerated $\mathrm{NO}_{3}-\mathrm{N}$ export due to the increase in outflow (Figure $4 \mathrm{~B}$ ).

\section{Conclusions}

Wetlands are important landscape features in the Southeastern USA Coastal Plain region with respect to water quality because they can act as $\mathrm{N}$ sinks. Their role as a natural water filter can be reversed, however, because they can act as an $\mathrm{N}$ source when precipitation events from tropical storms and hurricanes increase runoff and flooding causing more $\mathrm{N}$ transfer into the wetland. If the wetland's ability to retain this additional $\mathrm{N}$ is compromised, then $\mathrm{N}$ is released into downstream aquatic ecosystems. This study examined a North Carolina ISW's ability to retain as well as release $\mathrm{N}$ during different stream outflow events over a 3-yr period and also examined shifts in $\mathrm{N}$ storage pools using passive samplers and sediment TKN concentrations. Over 3 yr, most $\mathrm{NO}_{3}-\mathrm{N}$ and $\mathrm{NH}_{4}-\mathrm{N}$ mass loads were exported during $\mathrm{Q}_{b}$ events implying that under non-storm conditions the ISW was capable of retaining N. Results obtained in 1999, in contrast, revealed that three successive hurricane events grossly accelerated outflow $\mathrm{Q}$ and $\mathrm{N}$ releases. Not only was $\mathrm{N}$ export accelerated during the typical hurricane season, but a few FMS events during non-hurricane seasons also caused a large pulse of $\mathrm{NO}_{3}-\mathrm{N}$ export. During the non-hurricane seasons, this study showed that $\mathrm{NO}_{3}-\mathrm{N}$ mass loads are augmented when stream $\mathrm{NO}_{3}-\mathrm{N}$ concentrations are higher and by reduced $\mathrm{N}$ uptake via biological communities.

Regression analyses showed that annual $\mathrm{NO}_{3}-\mathrm{N}$ and $\mathrm{NH}_{4}-\mathrm{N}$ mass releases from this ISW were significantly correlated with $\mathrm{Q}_{t}$ flows, but the prediction of $\mathrm{N}$ export was weak to strong. This implies a modest ability to predict $\mathrm{NO}_{3}-\mathrm{N}$ and $\mathrm{NH}_{4}-\mathrm{N}$ export with $\mathrm{Q}_{t}$.

As $\mathrm{N}$ flowed into this ISW, internal and external forces caused by chemical equilibria, flow dynamics, and biological uptake can promote shifts in the abiotic and biotic $\mathrm{N}$ storage pools. This study examined only abiotic $\mathrm{N}$ storage pools such as bound to sediments or shifted between the water column and pore water $\mathrm{N}$ pools. These $\mathrm{N}$ storage pools were subject to perturbation by external and internal dynamics forces because both sediment TKN, pore water $\mathrm{NO}_{3}-\mathrm{N}$ and $\mathrm{NH}_{4}-\mathrm{N}$ concentrations shifted in response to hydrologic disturbances from 
storm events. Long-term monitoring of the ISW revealed that this ISW's ability to store/ release $\mathrm{N}$ was dependent on outflow $\mathrm{Q}$ characteristics, sediment movement, and $\mathrm{N}$ exchanges between sediments and pore water. This ISW can store N; however, most storage occurred during low out flow $\left(\mathrm{Q}_{b}\right)$ situations because flushing of stored $\mathrm{N}$ in pore water and associated sediments was minimal. When outflow is accelerated, hydrologic disturbances can flush $\mathrm{N}$ out because of equilibria shifts between pools as well as dispersion of N-enriched sediments. It is during these large hydrologic fluctuations associated with storm events when this ISW acts as a pronounced $\mathrm{N}$ source for downstream aquatic ecosystems.

\section{Acknowledgements}

Sincere gratitude is expressed to Dr. Maurice Cook, Dr. Frank Huminek (deceased), Mr. Mark Rice, and the North Carolina Cooperative Extension Service for project coordination and monitoring. This research project was partially funded by CSREES Grant No. 58-66570-11 entitled "Management practices to reduce non-point source pollution on a watershed basis". 'Mention of a specific product or vendor does not constitute a guarantee or warranty of the product by the US department of Agriculture or imply its approval to the exclusion of other products that may be suitable.

\section{Author details}

J. M. Novak ${ }^{1 *}$, A. A. Szogi ${ }^{1}$, K.C. Stone ${ }^{1}$, X. Chu ${ }^{2}$, D. W. Watts ${ }^{1}$ and M. H. Johnson ${ }^{1}$

*Address all correspondence to: jeff.novak@ars.usda.gov

1 USDA-ARS-Coastal Plains Soil, Water, and Plant Research Center, Florence, South Carolina, U.S. A.

2 Department of Civil Engineering, North Dakota State University, North Dakota, U. S. A.

\section{References}

[1] Paerl, H. W., Rudek, J., \& Mallin, M. A. (1990). Stimulation of phytoplankton production in coastal waters by natural rainfall input: Nutritional and trophic implications. Mar. biol., 107, 247-254.

[2] Rudek, J., Paerl, H. W., Mallin, M. A., \& Bates, P. W. (1991). Seasonal and hydrological control of phytoplankton nutrient limitation in the lower Neuse River Estuary, North Carolina. Mar. ecol. prog. ser., 75, 133-142. 
[3] Carpenter, S. R., Caraco, N. F., Correll, D. L., Howarth, R. W., Sharpley, A. N., \& Smith, V. H. (1998). Nonpoint pollution of surface waters with phosphorus and nitrogen. Ecol. appl., 8, 559-568.

[4] Howarth, R. W., Sharpley, A. N., \& Walker, D. (2002). Sources of nutrient pollution to coastal waters in the United States: Implications for achieving coastal water quality. Estuaries, 25, 656-676.

[5] Burkholder, J. M. (1998). Implications of harmful microalgae and heterotrophic dinoflagellates in management of sustainable marine fisheries. Ecol. appl., 8, 537-562.

[6] Bricker, S. B., \& Ferreira, J. (2008). ASSESTS eutrophication assessment: Method and application. Available: http://www.loicz.org/imperia/md/content/loicz/science/ assests_euthropphication_assessment.pdf. Accessed 2012 May 3.

[7] Van Dolah, P. R., \& Anderson, G. (1991). Effects of Hurricane Hugo on salinity and dissolved oxygen condition in the Charleston harbor. Estuary. j. coastal res., 8, 83-94.

[8] Winn, R., \& Knott, D. (1992). An evaluation of the survival of experimental populations exposed to hypoxia in the Savannah River Estuary. Mar. ecol. prog. ser., 88, 161-179.

[9] Paerl, H. W., Pickney, J. L., Fear, J. M., \& Peierls, B. L. (1998). Ecosystem responses to internal and watershed organic matter loading: Consequences for hypoxia in the eutrophying Neuse River Estuary, North Carolina, USA. Mar. ecol. prog. ser., 166, 17-25.

[10] Kellogg, R. L., Lander, C. H., Moffit, D. C., \& Gollehon, N. (2000). Manure nutrients relative to the capacity of croplands and pasturelands to assimilate nutrients: Spatial and temporal trends for the United States. USDA-NRCS-ERS Public. NPS00-05790, United States Dept. of Agriculture, Washington, D.C.

[11] Boyer, E. W., Goodale, C. L., Jaworski, N. A., \& Howarth, R. W. (2002). Anthropogenic nitrogen sources and relationships to riverine nitrogen export in the northeastern USA. Biogeochemistry, 57, 137-169.

[12] Mallin, M. A., \& Cahoon, L. B. (2003). Industrial animal production-A major source of nutrient and microbial pollution to aquatic ecosystems. Population and environ., 24, 369-385.

[13] Mallin, M. A., Posey, M. H., Mc Iver, M. R., Parsons, D. C., Ensign, S. H., \& Alphin, T. D. (2002). Impacts and recovery from multiple hurricanes in a Piedmont Coastal Plain river system. Bioscience, 52, 999-1010.

[14] NCDA (2009). Statistics-Livestock, Poultry and Dairy. North Carolina Department of Agriculture, Agricultural Statistics Division. Raleigh, North Carolina. Available: http://www.ncagr.com/stats/index.htm.Accessed 2012 May 3.

[15] Mallin, M. A., Cahoon, L. B., Parsons, D. C., \& Ensign, S. H. (2001). Effect of nitrogen and phosphorus loading on plankton in Coastal Plain blackwater streams. J. freshwater ecol., 16, 455-466. 
[16] Kellogg, R. L. (2000). Potential priority watersheds for protection of water quality from contamination by manure nutrients. Proc. Animal Residuals Manage. 12- 14 Nov 2000 Conf Water Environ. Feder. Alexandria, Virginia

[17] Galloway, J. N., Dentener, F. J., Capone, D. G., Boyer, E. W., Howarth, R. W., Seitzinger, S. P., Asner, G. P., Cleveland, C. C., Green, P. A., Holland, E. A., Karl, D. M., Michaels, A. F., Porter, J. H., Townsend, A. R., \& Vöosmarty, C. J. (2004). Nitrogen cycles: Past, present, and future. Biogeochemistry, 70, 153-226.

[18] Peterson, B. J., Wollheim, W. M., Mulholland, P. J., Webster, J. R., Meyer, J. L., Tank, J. L., Martí, E., Bowden, W. B., Valett, H. M., Hershey, A. E., Mc Dowell, W. L., Dodds, W. K., Hamilton, S. K., Gregory, S., \& Morrall, D. D. (2001). Control of nitrogen export from watersheds by headwater streams. Science, 292, 86-90.

[19] Szögi, A. A., Hunt, P. G., \& Humenik, F. J. (2003). Nitrogen distribution in soils of constructed wetlands treating lagoon wastewater. Soil sci. soc. am. j., 67, 1943-1951.

[20] Kadlec, R. H., \& Knight, R. L. (1996). Treatment wetlands. Lewis Publ., Boca Raton, Florida p., 365.

[21] Stober, J. T., O'Connor, J. T., \& Brazos, B. J. (1997). Winter and spring evaluations of a wetland for tertiary wastewater treatment. Water environ. res., 69, 961-968.

[22] Groffman, P. M., Dorsey, A. M., \& Mayer, P. M. (2005). N processing within geomorphic structures in urban streams. J. n. am. benthol. soc., 24, 613-625.

[23] Hunt, P. G., Stone, K. C., Humenik, F. J., Matheny, T. A., \& Johnson, M. H. (1999). Instream wetland mitigation of nitrogen contamination in a USA Coastal Plain stream. J. environ. qual., 28, 249-256.

[24] Stone, K. C., Hunt, P. G., Novak, J. M., Johnson, M. H., Watts, D. W., \& Humenik, F. J. (2004). Stream nitrogen changes in an eastern Coastal Plain watershed. J. soil water. conserv., 59, 66-72.

[25] Bales, J. D. (2003). Effects of Hurricane Floyd inland flooding, September-October 1999, on tributaries to Pamlico Sound, North Carolina. Estuaries , 26, 1319-1328.

[26] Novak, J. M., Szögi, A. A., Stone, K. C., Watts, D. W., \& Johnson, M. H. (2007). Dissolved phosphorus export from an animal waste impacted In-stream wetland: Response to tropical storm and hurricane disturbance. J. environ. qual., 36, 790-800.

[27] Daniels, R. B., Buol, S. W., Kleiss, H. J., \& Ditzler, C. A. (1999). Soil systems of North Carolina. Res. Bull., 314. North Carolina, State Univ., Raleigh, NC., p118.

[28] Novak, J. M., Stone, K. C., Watts, D. W., \& Johnson, M. H. (2003). Dissolved phosphorus transported during storm and base flow conditions from an agriculturally intensive southeastern Coastal Plain watershed. Trans. ASAE, 46, 1355-1363.

[29] State Climate Office of North Carolina. (2009). Daily rainfall recorded at Warsaw, North Carolina. State Climate office of North Carolina, Raleigh, North Carolina. 
[30] Lyne, V. D., \& Hollick, M. (1979). Stochastic time-variable rainfall-runoff modeling. Hydrology and Water Resource Symp. 10-12 Sept. 1979. Institute of Engineers Australia. Perth, Australia.

[31] Nahatan, R. J., \& Mc Mahon, T. A. (1990). Evaluation of automated techniques for baseflow and recession analysis. Water resour. res., 26, 1465-1473.

[32] U.S. Environmental Protection Agency (1983). Methods for chemical analysis of water and wastes. EPA-600/4-79-020. Environmental Monitoring and Support Lab, Office of Research and Development, USEPA, Cincinnati, Ohio.

[33] Novak, J. M., Stone, K. C., Szögi, A. A., Watts, D. W., \& Johnson, M. H. (2004). Dissolved phosphorus retention and release from a Coastal Plain in-stream wetland. J. environ. qual., 33, 394-401.

[34] National Oceanic and Atmospheric Association (2012). Hurricane Seasonal Patterns. Available: http://www.nhc.noaa.gov.Accessed 2012 May 4.

[35] Jordan, T. E., Correll, D. L., \& Weller, D. E. (1997). Relating nutrient discharges from watersheds to land use and stream flow variability. Water resour. res., 33, 2579-2590.

[36] Owens, L. B., Edwards, W. M., \& Keuren, R. W. (1991). Baseflow and stormflow transport of nutrients from mixed agricultural watersheds. J. environ. qual., 20, 407-414.

[37] Brenner, F. J., \& Mondok, J. J. (1995). Nonpoint source pollution potential in an agricultural watershed in northwestern Pennsylvania. Water resour. bull., 31, 1101-1112.

[38] Stone, K. C., Hunt, P. G., Johnson, M. H., \& Matheny, T. A. (1998). Nitrate-N distribution and trends in shallow groundwater on an Eastern Coastal Plains watershed. Trans. ASAE, 41, 59-64.

[39] van Kessel, J. F. (1977). Removal of nitrate from effluent following discharge on surface water. Water res., 11, 533-557.

[40] Reddy, K. R., Kadlec, R. H., Flaig, E., \& Gale, P. M. (1999). Phosphorus retention in streams and wetlands: A review. Crit. rev. environ. sci. tech., 29, 83-146.

[41] Birgand, F., Skaggs, R. W., Chescheir, G. M., \& Gilliam, J. W. (2007). Nitrogen removal in streams of agricultural catchments-A literature review. Crit. rev. environ. sci. tech., 37, 381-487.

[42] Reddy, K. R., \& Patrick, W. H., Jr. (1984). Nitrogen transformations and loss in flooded soils and sediments. Crit. rev. environ. control, 13, 273-309.

[43] Reddy, K. R., Patrick, W. H., \& Jr Phillips, R. E. (1976). Ammonium diffusion as a factor in nitrogen loss from flooded soils. Soil sci. soc. am. proc., 40, 528-533. 